\title{
UMPAK-UMPAK DI SITUS CANDI SANGGAR
}

\author{
Sugeng Riyanto \\ (Balai Arkeologi Yogyakarta)
}

\begin{abstract}
Artifacts, such as ceramics, potteries, and 18 propstones are found in the vicinity of Chandi Sanggar. By analyzing the propstones, it turned out that they have many varieties on the size, and the technology. It is remarkable to observe that the surface of the propstones showed variants: smooth, rough, and the combination of it, whereas their size are also different: big, medium, and small. The differences are related to the structure of Chandi Sanggar, since the propstones were found in context with it. Therefore it can be concluded that Chandi Sanggar was a compound, consisted of the main chandi and several supporting buildings.
\end{abstract}

Key words: Candi Sanggar, umpak, Gunung Bromo

\section{PENDAHULUAN}

Candi Sanggar terlatak di Dusun Wonogriyo, Desa Pusungmalang, Kecamatan Puspo, Kabupaten Pasuruan, Jawa Timur. Secara geomorfologis Candi Sanggar terletak di lereng Gunung Penanjakan, salah satu anak Gunung Bromo, pada ketinggian 1.340 meter di atas permukaan laut. Situs yang berada pada punggung bukit ini memiliki luas keseluruhan kurang lebih $20 \mathrm{~m} \times 25 \mathrm{~m}$ atau $500 \mathrm{~m}^{2}$. Balai Arkeologi Yogyakarta mengadakan penelitian di situs ini sejak tahun 2005 dan telah mendapatkan informasi dan pengetahuan, antara lain berupa:

1. Candi Sanggar hingga saat ini menjadi satu-satunya bangunan candi yang terletak di lereng Gunung Bromo

2. Candi Sanggar dibangun secara bertahap antara abad ke-14 sampai dengan abad ke-16 Masehi, atau semasa dengan Majapahit sebagaimana ditunjukkan oleh dua buah angka tahun, yaitu 1267 Saka (1345 M) dan 1431 Saka (1509 M)

3. Bangunan Candi Sanggar merupakan bangunan terbuka yang berbentuk punden berundak

4. Bangunan Candi Sanggar berlatar belakang keagamaan Hindu

5. Bangunan Candi Sanggar menghadap ke arah utara dan berorientasi pada puncak Gunung Bromo (Istari, 2007)

Selain memfokuskan pada arsitektur bangunan, tim penelitian juga memperoleh data berupa artefak yang meliputi keramik dan tembikar, serta umpak yang berjumlah 18 buah. Populasi umpak yang ditemukan sangat 
menarik perhatian, paling tidak dalam hal jumlah, variasi, serta sebagai konteks bangunan. Untuk itulah secara khusus perlu dilakukan pengamatan dan studi atas umpak-umpak ini dengan tujuan sebagai berikut:

1. Melakukan analisis aspek formal dan aspek metrik atas umpak-umpak yang ditemukan

2. Melakukan identifikasi umpak

3. Memperoleh gambaran hubungan populasi umpak dengan bangunan Candi Sanggar

Berdasarkan hal itu, perlu dilakukan pendekatan melalui deskripsi atas populasi umpak yang ditemukan beserta aspek metriknya. Hasil deskripsi tersebut digunakan untuk mengelompokkan umpak, berupa kategorisasi berdasarkan ukuran dan kategorisasi berdasarkan penggarapan. Melalui analisis formal dan analisis metrik diharapkan diperoleh informasi dan pengetahuan mengenai identifikasi atas populasi umpak Candi Sanggar serta hubunggannya dengan bangunan yang ada.

Pendekatan tersebut pada prinsipnya mengacu pada metode penelitian deskriptif analitis yang menurut Danim (2002: 41) bertujuan untuk mendeskripsikan suatu situasi atau area populasi tertentu yang bersifat faktual secara sistematis dan akurat. Deskripsi atas populasi umpak selanjutnya menjadi bahan untuk dianalisis, khususnya berkenaan dengan aspek bentuk dan aspek metriknya, sekaligus menjadi landasan untuk menyusun interpretasi. Keberadaan umpak-umpak di situs Candi Sanggar beserta atribut yang melekat dan variasi bentuk maupun ukurannya dalam batasan tertentu adalah fakta empirik yang dapat dianalisis untuk mendapatkan gambaran atas kecenderungan-kedenderungan yang ada. Proses studi ini pada prinsipnya juga tidak terlepas dari kerangka metode penelitian deskriptif analitik sebagaimana diuraikan oleh Sumanto (1995: 77).

\section{TEMUAN UMPAK DI SITUS CANDI SANGGAR}

\section{Sebaran dan Populasi}

Umpak yang ditemukan di situs Candi Sanggar merupakan temuan penduduk, dan dikumpulkan di sekitar bangunan candi, serta temuan hasil survei yang dilakukan oleh tim penelitian. Namun demikian, diperoleh keterangan bahwa umpak-umpak yang dikumpulkan oleh penduduk ditemukan tidak jauh dari bangunan candi. Demikian pula dengan umpak hasil survei, lokasi penemuan umpak tidak lebih dari radius 50 meter dari bangunan candi, sehingga dipastikan bahwa umpak-umpak ini merupakan bagian dari bangunan Candi Sanggar. 


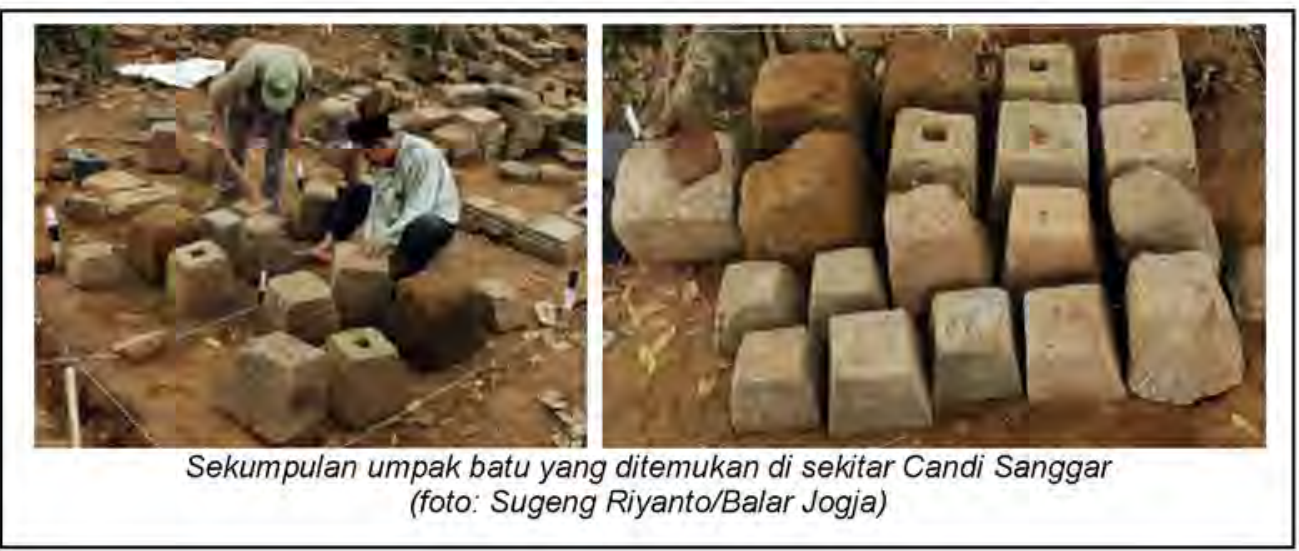

Seluruh umpak yang berjumlah 18 buah ini dibuat dari batu andesit dengan ukuran dan penggarapan yang beragam. Ragam ukuran umpak tampak pada tinggi umpak, yaitu antara $18 \mathrm{~cm}$ yang tertinggi dan $32 \mathrm{~cm}$ yang terrendah, penampang atas antara $15 \times 15 \mathrm{~cm}$ yang terkecil dan $24 \times$ $24,5 \mathrm{~cm}$ yang terbesar, penampang bawah yang terkecil berukuran $21 \times 21$ $\mathrm{cm}$ dan yang terbesar $37 \times 37 \mathrm{~cm}$. Namun demikian rentang ukuran tinggi, ukuran penampang atas, dan ukuran penampang bawah memiliki kombinasi yang tidak seragam dan cenderung acak sehingga dari 18 umpak yang ditemukan hampir semuanya memiliki varian yang berbeda.

Dari segi penggarapan, secara umum terbagi tiga, yaitu umpak dengan penggarapan kasar pada sisi permukaannya, umpak yang digarap secara halus, dan umpak yang memiliki permukaan sebagian halus dan sebagian kasar. Hanya dua buah umpak yang dilengkapi dengan hiasan, yaitu simbar, sisanya polos. Dari 18 buah umpak, tiga diantaranya memiliki lubang pada penampang atasnya, dan 15 lainnya rata pada permukaan atasnya. Dua dari tiga umpak yang berhias simbar memuat angka tahun yang berhuruf Jawa Kuna dan terbaca 1431 Saka atau 1509 Masehi.

Selengkapnya, populasi umpak yang ditemukan di situs Candi Sanggar adalah sebagai berikut.

Tabel 1. Populasi Umpak dari Situs Candi Sanggar

\begin{tabular}{|r|c|c|c|c|c|}
\hline NO & $\begin{array}{c}\text { TINGGI } \\
(\mathrm{Cm})\end{array}$ & $\begin{array}{c}\text { PENAMPANG } \\
\text { ATAS }(\mathrm{Cm})\end{array}$ & $\begin{array}{l}\text { PENAMPANG } \\
\text { BAWAH }(\mathrm{Cm})\end{array}$ & PENGGARAPAN & LUBANG \\
\hline 1 & 23 & $17,5 \times 18$ & $25 \times 25$ & HP & TA \\
\hline 2 & 30 & $24 \times 24,5$ & $30 \times 31$ & HP & TA \\
\hline 3 & 30 & $17 \times 17$ & $26 \times 26$ & HP & TA \\
\hline 4 & 17 & $15 \times 15$ & $22 \times 24$ & HP & TA \\
\hline 5 & 32 & $27 \times 27$ & $35 \times 36$ & HP & TA \\
\hline
\end{tabular}




\begin{tabular}{|r|c|c|c|c|c|}
\hline 6 & 32 & $17 \times 18$ & $23 \times 27$ & HP & TA \\
\hline 7 & 18 & $15 \times 15$ & $21 \times 21$ & HP & TA \\
\hline 8 & 21 & $18 \times 18$ & $24 \times 25$ & HP & TA \\
\hline 9 & 21,5 & $17 \times 17,5$ & $24 \times 24$ & HP & TA \\
\hline 10 & 32 & $27 \times 28$ & $37 \times 37$ & KP & TA \\
\hline 11 & 30,5 & $17,5 \times 19$ & $25,5 \times 28$ & SHP & TA \\
\hline 12 & 31 & $17 \times 19$ & $28 \times 29$ & SHP & TA \\
\hline 13 & 19 & $15 \times 16,5$ & $21 \times 23$ & HP & TA \\
\hline 14 & 29 & $22 \times 23$ & $26,5 \times 28$ & HP, LUBANG & $6 \times 7 \times(5)$ \\
\hline 15 & 28 & $23 \times 23,5$ & $30 \times 30$ & KP & TA \\
\hline 16 & 29,5 & $23 \times 23$ & $31 \times 31$ & KP & TA \\
\hline 17 & 29 & $21 \times 21$ & $30 \times 30$ & $\begin{array}{c}\text { HH, SIMBAR, } \\
\text { LUBANG, 1431 S }\end{array}$ & $6 \times 6 \times(5)$ \\
\hline 18 & 29 & $21 \times 21$ & $30 \times 30$ & $\begin{array}{c}\text { HH, SIMBAR, } \\
\text { LUBANG, } 1431 \text { S }\end{array}$ & $6 \times 6 \times(5)$ \\
\hline
\end{tabular}

Keterangan:

- HP : Halus, Polos

- KP : Kasar, Polos

- SHP : Setengah Halus, Polos

- $\mathrm{HH}$ : Halus, Berhias

- TA : Tidak Ada

\section{Analisis Formal dan Analisis Metrik}

Varian yang diperlihatkan oleh kombinasi antara ukuran dan penggarapan menjadi menarik untuk dicermati lebih lanjut, khususnya berkaitan dengan dua hal, yaitu makna variasi umpak dan kaitannya dengan bangunan candi. Untuk itu diperlukan analisis khusus yang mencakup analisis formal serta analisis metrik untuk mendapatkan informasi makna dari kehadiran variasi bentuk, dan ukuran umpak dalam kaitannya dengan bangunan Candi Sanggar.

Hasil analisis adalah sebagai berikut.

Gambaran populasi umpak menggambarkan dua jenis data, yaitu metrik atau kuantitatif, dan data kualitatif. Gambaran kualitatif yang langsung dapat digunakan adalah kategori penggarapan, di sana terdapat beberapa jenis penggarapan, yaitu halus dan polos (HP), kasar dan polos $(\mathrm{KP})$, setengah halus dan polos (SHP), serta halus berhias $(H H)$. Secara kualitatif, angka-angka yang tertera pada tabel sebenarnya dapat menggambarkan banyak hal, seperti umpak dengan kategori rendah, sedang, tinggi; umpak berbentuk meruncing, proporsional, besar, dan kecil. Namun untuk itu diperlukan pendekatan khusus dan cenderung 
menggunakan acuan arbitrer untuk mendapatkan gambaran kualitatif atas angka-angka tersebut.

Kategori tinggi (KATING) umpak didasarkan estimasi arbitrer ke dalam empat kategori, yaitu rendah (R), sedang (S), tinggi ( $T$ ), dan sangat tinggi (ST). Kategori umpak rendah adalah umpak dengan ukuran tinggi < $20 \mathrm{~cm}$, kategori sedang berukuran tinggi antara $20-25 \mathrm{~cm}$, kategori tinggi berukuran $26-30 \mathrm{~cm}$, dan sangat tinggi adalah umpak yang berukuran lebih dari $30 \mathrm{~cm}$. Hasil analisis tersebut adalah sebagai berikut.

Tabel 2. Kategori Tinggi Umpak

\begin{tabular}{|c|c|c|c|}
\hline NO & $\begin{array}{c}\text { TINGGI } \\
(\mathbf{C m})\end{array}$ & $\begin{array}{c}\text { KATEGORI TINGGI } \\
\text { (KATING) }\end{array}$ & KETERANGAN \\
\hline 1 & 23 & $\mathrm{~S}$ & Sedang \\
\hline 2 & 30 & $\mathrm{~T}$ & Tinggi \\
\hline 3 & 30 & $\mathrm{~T}$ & Tinggi \\
\hline 4 & 17 & $\mathrm{R}$ & Rendah \\
\hline 5 & 32 & $\mathrm{ST}$ & Sangat Tinggi \\
\hline 6 & 32 & $\mathrm{ST}$ & Sangat Tinggi \\
\hline 7 & 18 & $\mathrm{R}$ & Rendah \\
\hline 8 & 21 & $\mathrm{~S}$ & Sedang \\
\hline 9 & 21,5 & $\mathrm{~S}$ & Sedang \\
\hline 10 & 32 & $\mathrm{ST}$ & Sangat Tinggi \\
\hline 11 & 30,5 & $\mathrm{~T}$ & Tinggi \\
\hline 12 & 31 & $\mathrm{~T}$ & Tinggi \\
\hline 13 & 19 & $\mathrm{R}$ & Rendah \\
\hline 14 & 29 & $\mathrm{~T}$ & Tinggi \\
\hline 15 & 28 & $\mathrm{~T}$ & Tinggi \\
\hline 16 & 29,5 & $\mathrm{~T}$ & Tinggi \\
\hline 17 & 29 & $\mathrm{~T}$ & Tinggi \\
\hline 18 & 29 & $\mathrm{~T}$ & Tinggi \\
\hline
\end{tabular}

Kategori penampang atas (KAT PENAT) dihasilkan berdasarkan perhitungan pada perbandingan antara lebar rata-rata penampang atas dengan tinggi umpak. Perhitungan ini menghasilkan indeks persentase perbandingan tersebut dan selanjutnya secara arbitrer digolongkan ke dalam kecenderungan orientasi garis vertikal umpak, yaitu meruncing, proporsional, serta melurus. Kategori orientasi garis vertikal umpak yang meruncing adalah umpak dengan indeks penampang atas (IND PENAT) kurang dari $70 \%$, orientasi proporsional adalah umpak dengan indeks penampang atas antara $70 \%$ hingga $80 \%$, dan orientasi melurus adalah umpak dengan indeks penampang atas lebih dari $80 \%$.

Hasil analisis terhadap penampang atas adalah sebagai berikut: 
Tabel 3. Kategori Ukuran Penampang Atas

\begin{tabular}{|c|c|c|c|}
\hline NO & $\begin{array}{c}\text { UKURAN } \\
\text { PENAMPANG } \\
\text { ATAS } \\
\text { (PENAT/Cm) }\end{array}$ & $\begin{array}{c}\text { INDEKS } \\
\text { PENAMPANG } \\
\text { ATAS } \\
\text { (PENAT) }\end{array}$ & $\begin{array}{c}\text { KATEGORI } \\
\text { PENAMPANG } \\
\text { ATAS } \\
\text { (PENAT) }\end{array}$ \\
\hline 1 & $17,5 \times 18$ & 72 & Proporsional \\
\hline 2 & $24 \times 24,5$ & 79 & Proporsional \\
\hline 3 & $17 \times 17$ & 65,4 & Meruncing \\
\hline 4 & $15 \times 15$ & 62,5 & Meruncing \\
\hline 5 & $27 \times 27$ & 75 & Proporsional \\
\hline 6 & $17 \times 18$ & 66,6 & Meruncing \\
\hline 7 & $15 \times 15$ & 71,4 & Proporsional \\
\hline 8 & $18 \times 18$ & 72 & Proporsional \\
\hline 9 & $17 \times 17,5$ & 72,9 & Proporsional \\
\hline 10 & $27 \times 28$ & 75,7 & Proporsional \\
\hline 11 & $17,5 \times 19$ & 67,8 & Meruncing \\
\hline 12 & $17 \times 19$ & 65,5 & Meruncing \\
\hline 13 & $15 \times 16,5$ & 71,7 & Proporsional \\
\hline 14 & $22 \times 23$ & 82,1 & Melurus \\
\hline 15 & $23 \times 23,5$ & 78,3 & Proporsional \\
\hline 16 & $23 \times 23$ & 74,2 & Proporsional \\
\hline 17 & $21 \times 21$ & 70 & Proporsional \\
\hline 18 & $21 \times 21$ & 70 & Proporsional \\
\hline
\end{tabular}

Ukuran penampang bawah (PENBA) dianalisis untuk menghasilkan indeks penampang bawah (IND PENBA), dengan perhitungan persentase ukuran rata-rata penampang bawah terhadap tinggi umpak. Indeks yang dihasilan kemudian dikelompokan secara arbitrer ke dalam kategori penampang bawah (KAT PENBA) yang meliputi umpak pendek, umpak ramping, dan umpak proporsional. Umpak dengan kategori ramping adalah umpak dengan indeks penampang bawah kurang dari $100 \%$, umpak proporsional memiliki indeks antara $100 \%$ hingga $120 \%$, dan umpak pendek adalah umpak dengan indeks penampang bawah di atas $120 \%$.

Selengkapnya, hasil analisis terhadap penampang bawah umpakumpak Candi Sanggar adalah sebagai berikut:

Tabel 4. Kategori Ukuran Penampang Bawah

\begin{tabular}{|c|c|c|c|}
\hline NO & $\begin{array}{c}\text { UKURAN } \\
\text { PENAMPANG } \\
\text { BAWAH } \\
\text { (PENBA/Cm)) }\end{array}$ & $\begin{array}{c}\text { INDEKS } \\
\text { PENAMPANG } \\
\text { BAWAH } \\
\text { (PENBA) }\end{array}$ & $\begin{array}{c}\text { KATEGORI } \\
\text { PENAMPANG } \\
\text { BAWAH } \\
\text { (PENBA) }\end{array}$ \\
\hline 1 & $25 \times 25$ & 108,7 & Proporsional \\
\hline 2 & $30 \times 31$ & 101,7 & Proporsional \\
\hline 3 & $26 \times 26$ & 86,7 & Ramping \\
\hline 4 & $22 \times 24$ & 135,3 & Pendek \\
\hline
\end{tabular}




\begin{tabular}{|c|c|c|c|}
\hline 5 & $35 \times 36$ & 110,9 & Proporsional \\
\hline 6 & $23 \times 27$ & 78,1 & Ramping \\
\hline 7 & $21 \times 21$ & 116,7 & Proporsional \\
\hline 8 & $24 \times 25$ & 116,7 & Proporsional \\
\hline 9 & $24 \times 24$ & 111,6 & Proporsional \\
\hline 10 & $37 \times 37$ & 115,6 & Proporsional \\
\hline 11 & $25,5 \times 28$ & 87,7 & Ramping \\
\hline 12 & $28 \times 29$ & 91,9 & Ramping \\
\hline 13 & $21 \times 23$ & 115,8 & Proporsional \\
\hline 14 & $26,5 \times 28$ & 94 & Ramping \\
\hline 15 & $30 \times 30$ & 107,1 & Proporsional \\
\hline 16 & $31 \times 31$ & 105,1 & Proporsional \\
\hline 17 & $30 \times 30$ & 103,4 & Proporsional \\
\hline 18 & $30 \times 30$ & 103,4 & Proporsional \\
\hline
\end{tabular}

Kategori ukuran umpak (KAT UKUR) secara umum dianalisis dengan mengalikan ukuran tinggi umpak dikalikan ukuran rata-rata penampang atas dikalikan ukuran penampang bawah (TINGGI X PENAT X PENBA). Hasil perkalian tersebut menjadi indeks ukuran umpak (IND UKUR) dan secara arbitrer dikelompokkan ke dalam kategori umpak kecil, umpak sedang, dan umpak besar.

Umpak berkategori ukuran kecil adalah umpak dengan indeks ukuran kurang dari 10.000, umpak sedang adalah umpak dengan indeks ukuran antara 10.000 hingga 13.000 , dan umpak besar mempunyai indeks ukuran di atas 13.000 .

Selengkapnya, hasil analisis terhadap ukuran umum umpak adalah sebagai berikut:

Tabel 5. Kategori Ukuran Umpak

\begin{tabular}{|c|c|c|}
\hline NO & $\begin{array}{c}\text { INDEKS } \\
\text { UKURAN }\end{array}$ & $\begin{array}{c}\text { KATEGORI } \\
\text { UKURAN }\end{array}$ \\
\hline 1 & 10.350 & Sedang \\
\hline 2 & 13.500 & Besar \\
\hline 3 & 13.500 & Besar \\
\hline 4 & 7.650 & Kecil \\
\hline 5 & 14.400 & Besar \\
\hline 6 & 14.400 & Besar \\
\hline 7 & 8.100 & Kecil \\
\hline 8 & 9.450 & Kecil \\
\hline 9 & 9.675 & Kecil \\
\hline 10 & 14.400 & Besar \\
\hline 11 & 13.725 & Besar \\
\hline 12 & 13.950 & Besar \\
\hline 13 & 8.550 & Kecil \\
\hline 14 & 13.050 & Besar \\
\hline
\end{tabular}




\begin{tabular}{|c|c|c|}
\hline 15 & 12.600 & Sedang \\
\hline 16 & 13.275 & Besar \\
\hline 17 & 13.050 & Besar \\
\hline 18 & 13.050 & Besar \\
\hline
\end{tabular}

Dari segi penggarapan, umpak-umpak dapat dikategorikan berdasarkan halus atau kasar dan ada hiasan atau polos. Dari 18 umpak yang ditemukan, umpak-umpak tersebut terdiri atas umpak halus polos (HP), umpak kasar polos (KP) umpak setengah halus polos (SHP), dan umpak halus berhias $(\mathrm{HH})$. Untuk lebih jelas dalam kategorisi maka jenis umpak tersebut digolongkan ke dalam kategori penggarapan (KAT GAR) berdasarkan nilai arbitrer, sehingga menghasilkan kategori 1 (kasar polos), kategori 1,5 (setengah halus polos), kategori 2 (halus polos), dan kategori 3 (halus berhias).

Selengkapnya kategorisasi secara arbitrer berdasarkan penggarapan tersebut adalah sebagai berikut:

Tabel 6. Kategori Penggarapan Umpak

\begin{tabular}{|c|c|c|}
\hline NO & PENGGARAPAN & $\begin{array}{c}\text { KATEGORI } \\
\text { PENGGARAPAN } \\
\text { (KAT GAR) }\end{array}$ \\
\hline 1 & $\mathrm{HP}$ & 2 \\
\hline 2 & $\mathrm{HP}$ & 2 \\
\hline 3 & $\mathrm{HP}$ & 2 \\
\hline 4 & $\mathrm{HP}$ & 2 \\
\hline 5 & $\mathrm{HP}$ & 2 \\
\hline 6 & $\mathrm{HP}$ & 2 \\
\hline 7 & $\mathrm{HP}$ & 2 \\
\hline 8 & $\mathrm{HP}$ & 2 \\
\hline 9 & $\mathrm{HP}$ & 2 \\
\hline 10 & $\mathrm{KP}$ & 1 \\
\hline 11 & $\mathrm{SHP}$ & 1,5 \\
\hline 12 & $\mathrm{SHP}$ & 1,5 \\
\hline 13 & $\mathrm{HP}$ & 2 \\
\hline 14 & $\mathrm{HP}$, LUBANG & 2 \\
\hline 15 & $\mathrm{KP}$ & 1 \\
\hline 16 & $\mathrm{KP}$ & 1 \\
\hline 17 & $\mathrm{H}$, SIMBAR, LUBANG, $143^{`}$ & 3 \\
\hline 18 & $\mathrm{H}$, SIMBAR, LUBANG, $143^{\circ}$ & 3 \\
\hline
\end{tabular}

\section{Identifikasi Umpak Berdasarkan Ukuran}

Jika ukuran umum umpak dijadikan sebagai standar maka berdasarkan analisis kualitatif tersebut didapatkan distribusi umpak yang berpopulasi 18 buah yang terdiri atas umpak berkategori kecil 5 buah, 
umumnya proporsional (1 pendek meruncing), rendah hingga sedang, halus dan polos, seperti terlihat pada tabel berikut ini.

Tabel 7. Identifikasi Umpak Berukuran Kecil

\begin{tabular}{|c|c|c|c|c|c|}
\hline KATING & $\begin{array}{c}\text { KAT } \\
\text { PENAT }\end{array}$ & $\begin{array}{c}\text { KAT } \\
\text { PENBA }\end{array}$ & $\begin{array}{c}\text { KAT } \\
\text { UKUR }\end{array}$ & GARAP & $\begin{array}{c}\text { KAT } \\
\text { GAR }\end{array}$ \\
\hline R & Meruncing & Pendek & Kecil & HP & 2 \\
\hline R & Proporsional & Proporsional & Kecil & HP & 2 \\
\hline S & Proporsional & Proporsional & Kecil & HP & 2 \\
\hline S & Proporsional & Proporsional & Kecil & HP & 2 \\
\hline R & Proporsional & Proporsional & Kecil & HP & 2 \\
\hline
\end{tabular}

Umpak dengan ukuran sedang berjumlah 2 buah, semuanya proporsional, sedang hingga tinggi, dengan penggarapan halus polos dan kasar polos. Tabel hasil analisis tersebut adalah sebagai berikut:

Tabel 8. Identifikasi Umpak Berukuran Sedang

\begin{tabular}{|c|c|c|c|c|c|}
\hline KATING & $\begin{array}{c}\text { KAT } \\
\text { PENAT }\end{array}$ & $\begin{array}{c}\text { KAT } \\
\text { PENBA }\end{array}$ & $\begin{array}{c}\text { KAT } \\
\text { UKUR }\end{array}$ & GARAP & $\begin{array}{c}\text { KAT } \\
\text { GAR }\end{array}$ \\
\hline S & Proporsional & Proporsional & Sedang & HP & 2 \\
\hline T & Proporsional & Proporsional & Sedang & KP & 1 \\
\hline
\end{tabular}

Umpak berkategori besar berjumlah 10 buah dengan varian yang cukup kompleks, tetapi umumnya tinggi dan sangat tinggi, ramping hingga proporsional, meruncing, dan bahkan ada yang berorientasi garis vertikal meulurus. Penggarapan mulai dari kategori 1 hingga 3 yang berarti sangat kompleks dari kasar polos, halus polos, setengah halus polos, hingga halus berhias. Berikut ini adalah indentifikasi umpak berukuran besar tersebut:

Tabel 9. Identifikasi Umpak Berukuran Besar

\begin{tabular}{|c|c|c|c|c|c|}
\hline KATING & $\begin{array}{c}\text { KAT } \\
\text { PENAT }\end{array}$ & $\begin{array}{c}\text { KAT } \\
\text { PENBA }\end{array}$ & $\begin{array}{c}\text { KAT } \\
\text { UKUR }\end{array}$ & GARAP & $\begin{array}{c}\text { KAT } \\
\text { GAR }\end{array}$ \\
\hline $\mathrm{T}$ & Proporsional & Proporsional & Besar & HP & 2 \\
\hline $\mathrm{T}$ & Meruncing & Ramping & Besar & HP & 2 \\
\hline ST & Proporsional & Proporsional & Besar & HP & 2 \\
\hline ST & Meruncing & Ramping & Besar & HP & 2 \\
\hline ST & Proporsional & Proporsional & Besar & KP & 1 \\
\hline$T$ & Meruncing & Ramping & Besar & SHP & 1,5 \\
\hline$T$ & Meruncing & Ramping & Besar & SHP & 1,5 \\
\hline$T$ & Melurus & Ramping & Besar & HP, LUBANG & 2 \\
\hline$T$ & Proporsional & Proporsional & Besar & $\begin{array}{c}\text { H, SIMBAR, } \\
\text { LUBANG, } \\
\text { 1431 Saka }\end{array}$ & 3 \\
\hline$T$ & Proporsional & Proporsional & Besar & $\begin{array}{c}\text { H, SIMBAR, } \\
\text { LUBANG, } \\
\text { 1431 Saka }\end{array}$ & 3 \\
\hline
\end{tabular}




\section{Umpak dan Bangunan Candi Sanggar}

Hasil analisis secara terbatas menghasilkan beberapa pemikiran berkaitan dengan keberadaan Candi Sanggar. Inti dari pemikiran ini adalah bahwa Candi Sanggar bukan bangunan tunggal, tetapi merupakan kompleks bangunan yang terdiri atas bangunan induk dan bangunan pendukung.

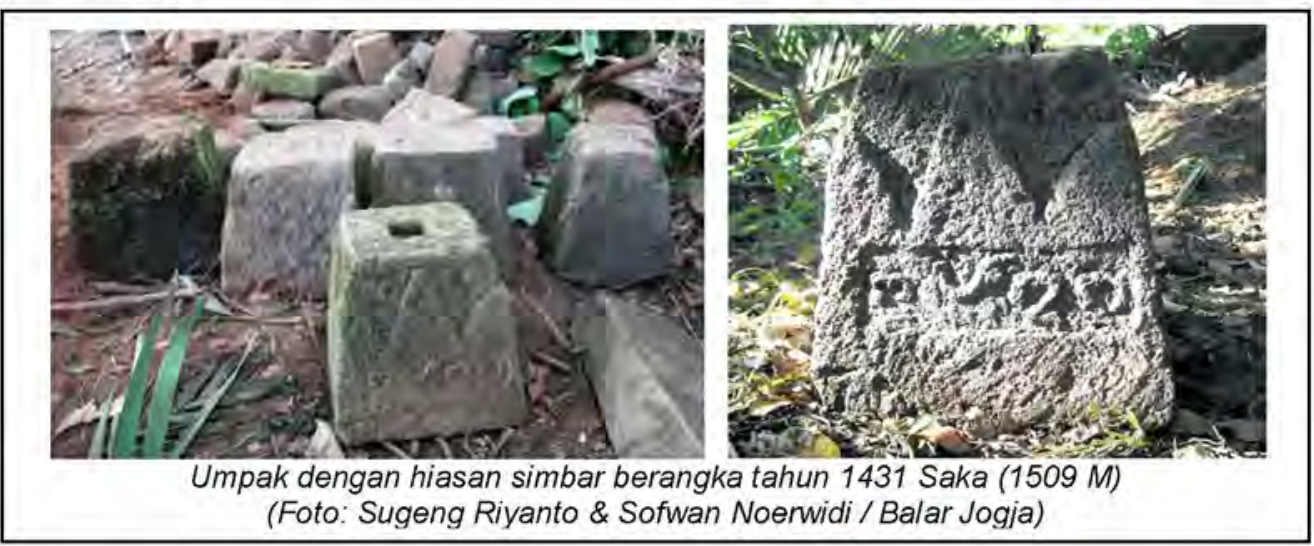

besar mengindikasikan bahwa bangunan Candi Sanggar merupakan bangunan yang besar pula. Adapun keberadaan umpak-umpak yang lebih kecil menandakan bahwa bangunan Candi Sanggar cukup kompleks dan mungkin dilengkapi dengan bangunan yang lebih kecil, tentu saja dengan fungsi yang berbeda pula. Kompleksitas bangunan Candi Sanggar juga dicerminkan dari variasi bentuk umpak, meskipun dominan proporsional, namun ada juga umpak dengan bentuk meruncing, pendek, ramping, bahkan cenderung lurus. Demikian pula dengan keberadaan umpak dengan cara penggarapan yang bervariasi, dari kasar polos, halus polos, dan halus berhias yang

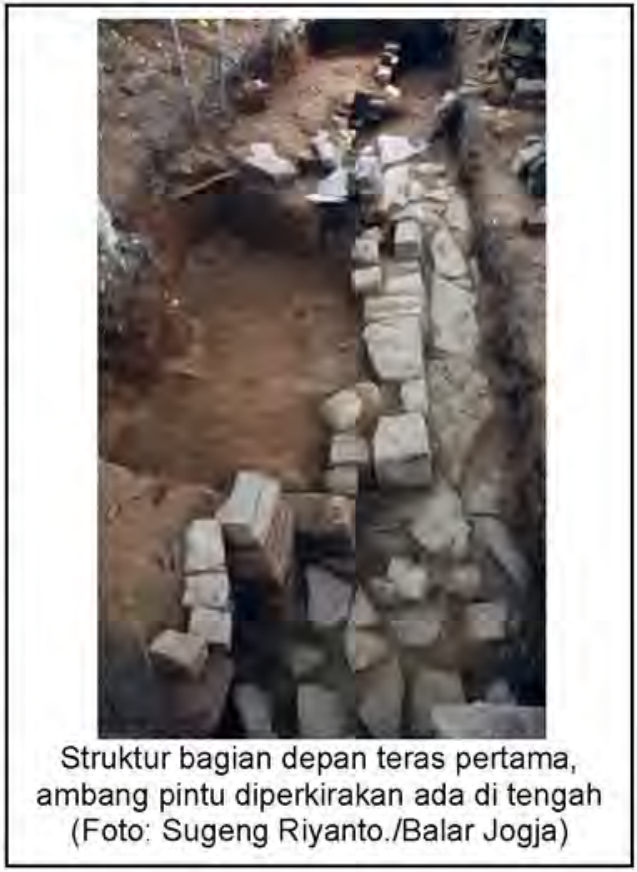
juga menandakan fungsi teknis dan fungsi estetis yang beragam pula dalam kompleks bangunan Candi Sanggar.

Selain unik karena merupakan satu-satunya bangunan candi yang terletak di lereng Bromo, Candi Sanggar juga menjadi penting artinya ketika dikaitkan dengan kerajaan Majapahit. Keterkaitan bangunan ini dengan Majapahit selain ditunjukkan oleh angka tahun yang ditemukan, yaitu 1267 
Saka (1345 M), dan 1431 Saka (1509 M), juga tampak pada bentuk bangunannya, yang berupa bangunan terbuka berbentuk punden berundak. Sebagai bangunan suci yang digunakan untuk proses pemujaan, struktur bangunan cenderung menyatu dengan lingkungannya. Struktur bangunan yang "rebah" mengikuti bentuk lereng ini terbagi menjadi tiga halaman utama, yaitu halaman pertama yang terletak di bawah, halaman kedua terletak di tengah dan halaman ketiga berada paling atas serta dianggap paling sakral (Istari, 2007: 4).

Situs dan bangunan yang berada di lereng bukit menyebabkannya mendapat ancaman kerusakan yang serius sehingga diperlukan perhatian khusus dalam rangka mengamankan dan melestarikan Candi Sanggar. Pada gilirannya, kelestarian situs dan bangunan Candi Sanggar dalam batas tertentu dapat menjadi acuan pemanfaatan yang didukung dengan informasi dan pengetahuan hasil penelitian arkeologi.

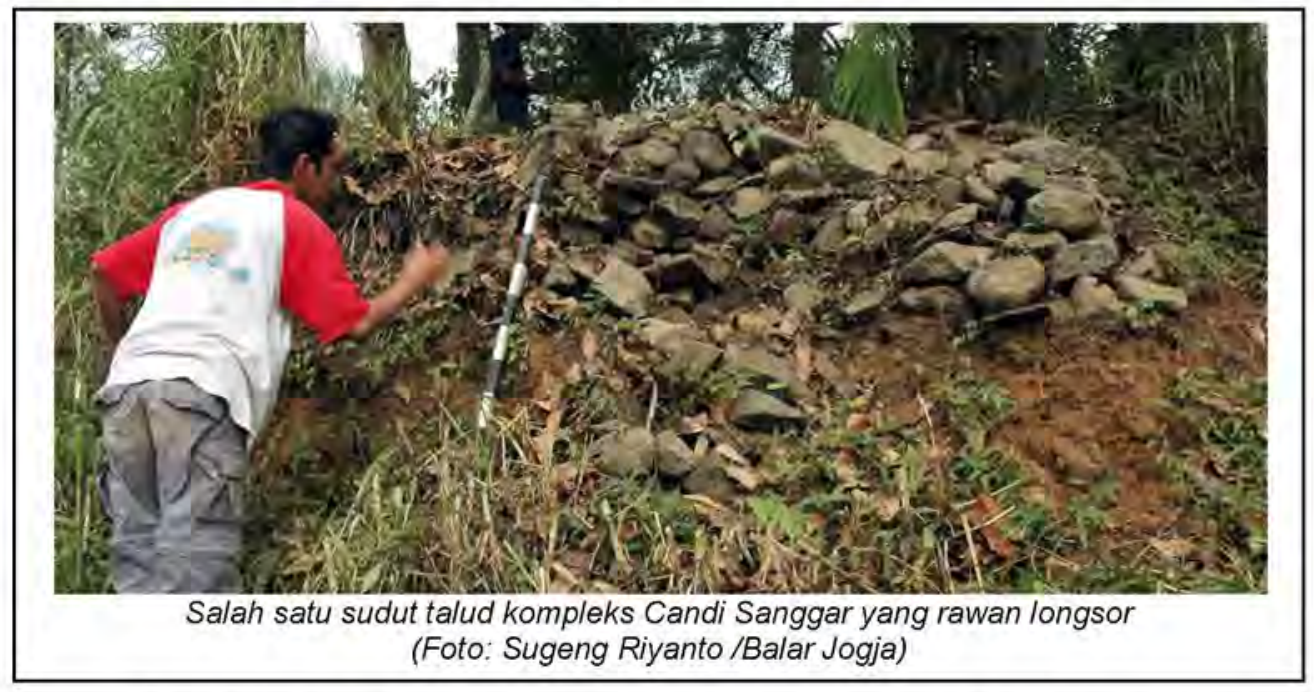

Sementara itu, pelestarian dan pemanfaatan, khususnya pariwisata, memang memiliki hubungan yang resiprokal, sekaligus merupakan dua kepentingan yang strategis (Haryono, 2003: 9). Beberapa kerangka pemikiran dengan hubungan resiprokal ini antara lain adalah perlunya mempelajari konsep peddle or perish (Macleod, 1977: 63-72) yang pada intinya menyatakan bahwa benda cagar budaya dapat terancam keletariannya apabila tidak dimanfaatkan. Pemanfaatan inilah yang harus didukung dengan konsep pelestarian sesuai dengan kondisi Candi Sanggar serta informasi dan pengetahuan yang telah dihasilkan. Diharapkan konsep ini dapat dipahami oleh seluruh stakeholders agar Candi Sanggar tidak hanya lestari tetapi juga dapat dimanfaatkan oleh berbagai kalangan, termasuk makna kultural yang terkandung di dalamnya. 


\section{PENUTUP}

Temuan 18 buah umpak di sekitar lokasi bangunan menunjukkan bahwa selain bangunan utama yang berupa teras-teras, dahulu juga terdapat bangunan lain yang mendukung dan menjadi bagian dari kompleks bangunan. Di sisi lain, hasil analisis atas varian yang ada pada umpak menunjukkan bahwa bangunan-bangunan pendukung juga memiliki variasi, terutama dalam hal ukurannya. Artinya, Candi Sanggar adalah bangunan yang kompleks dan mungkin dilengkapi dengan bangunan lain yang lebih kecil, tentu saja dengan fungsi yang berbeda pula.

Kompleksitas bangunan Candi Sanggar juga dicerminkan dari variasi bentuk umpak. Meskipun dominan proporsional, namun ada juga umpak dengan bentuk meruncing, pendek, ramping, bahkan cenderung lurus. Demikian pula keberadaan umpak dengan cara penggarapan yang bervariasi, dari kasar polos, halus polos, dan halus berhias, juga menandakan fungsi teknis dan fungsi estetis yang beragam pula dalam kompleks bangunan Candi Sanggar.

Secara alamiah, terutama karena letaknya di punggung bukit yang rawan longsor, Candi Sanggar secara langsung terancam kelestariannya. Di sisi lain, kelestarian situs dan bangunan ini memiliki arti penting di dalam kerangka akademik, antara lain karena Candi Sanggar hingga saat ini merupakan satu-satunya bangunan candi yang ada di lereng Gunung Bromo serta merupakan mata rantai jejak kejayaan kerajaan Majapahit. Pada gilirannya, kelestarian serta informasi dan pengetahuan yang terkandung di balik bangunan Candi Sanggar diharapkan dapat dimanfaatkan untuk berbagai kepentingan, khususnya kepentingan ilmiah dan pendidikan. 


\section{KEPUSTAKAAN}

Danim, Sudarwan. 2002. Menjadi Peneliti Kualitatif. Bandung: Pustaka Setia.

Haryono, Timbul. 2003. "Pengembangan dan Pemanfaatan Aset Budaya dalam Pelaksanaan Otonomi Daerah". Makalah disampaikan pada Rapat Koordinasi Kebudayaan dan Pariwisata diselenggarakan oleh Kementrian Kebudayaan dan Pariwisata di Jakarta pada tanggal 2527 Maret 2003.

Istari, TM Rita, 2007. Laporan Penelitian Arkeologi Arsitektur Candi Sanggar di Lereng Gunung Bromo Kabupaten Pasuruan (Tahap III). Balai Arkeologi Yogyakarta. Tidak Terbit.

Macleod, Donald G. 1977. "Peddle or Perish: Archaeological Marketing from Concept to Product Delivery". Michael B. Schiffer \& George J. Gumerman (eds.). Conservation Archaeology A Guide for Cultural Resources Management Studies. New York: Academic Press. pp. 63-72.

Sumanto, 1995. Metodologi Penelitian Sosial dan Pendidikan. Yogyakarta: Penerbit Andi Offset. 

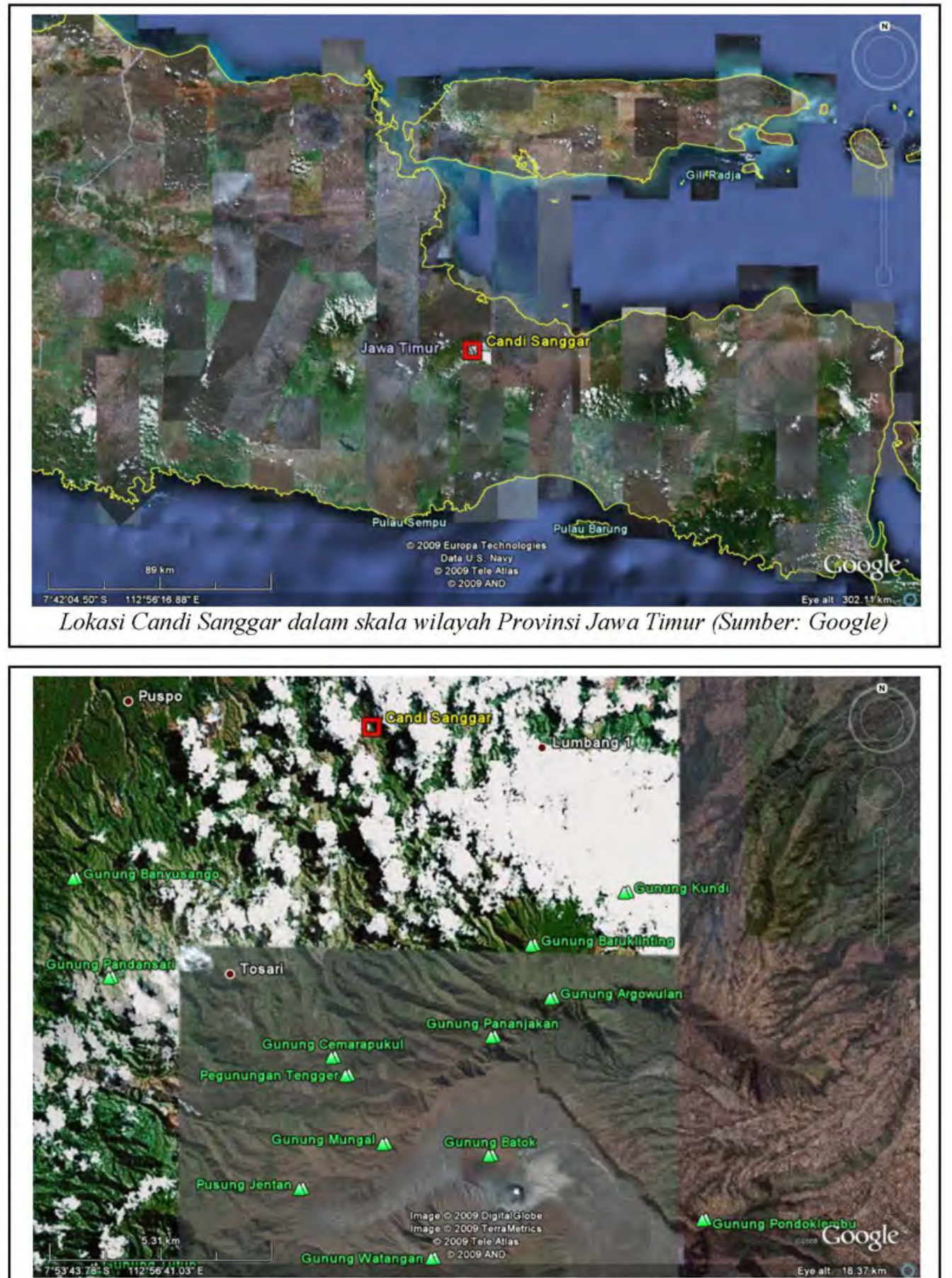

Posisi Candi Sanggar area lereng Bromo (Sumber: Google) 